\title{
Diatomitin Kilis Keçilerinin Kan Selenyum ve Çinko Değerleri ile Canlı Ağırlık Değişimlerine Etkileri
}

\author{
Mehmet Şevki ÇADIRCI ${ }^{1, a, *}$, Mehmet İRIADAM ${ }^{2, b}$ \\ ${ }^{1}$ TOBB Fen Lisesi Müdürlüğ̈̈, Haliliye, Şanlıurfa, Türkiye \\ ${ }^{2}$ Harran Üniversitesi, Veteriner Fakültesi, Fizyoloji Anabilim Dalı, Şanlıurfa, Türkiye \\ aORCID: 0000-0002-6311-7578, ' ${ }^{\mathrm{O} O R C I D: 0000-0002-9694-6014}$
}

Geliș Tarihi: 01.07.2021

Kabul Tarihi: 01.11.2021

\begin{abstract}
Özet: Diatomit genellikle çiftlik hayvanları için yem bileşeni ve aynı zamanda alternatif bir antelmintik olarak kullanılan organik yem katkı maddesidir. Bu çalışmada Kilis Keçilerinin rasyonlarına belli oranlarda katılan diatomitin kanda Selenyum (Se) ve çinko (Zn) değerleri ile keçilerin canlı ağırlıklarına olan etkisinin incelenmesi amaçlanmıştır. Araştırmada 18-42 aylık, erkek ve dişi, 23-50 kg ağırlı̆ında 15 Kilis keçisi kullanılmıştır. Hayvanlar kontrol grubu, \%5 ve \%10 diatomit katkılı grup olarak 3 gruba ayrılmışır. I. Kontrol grubunun rasyonlarına diatomit katılmamıştır. II. Gruptaki hayvanların rasyonlarına günlük kuru yem miktarının \%5'i kadar ve III. Gruptaki hayvanların rasyonlarına günlük kuru yem miktarının \%10'u kadar diatomit katkısı yapılarak 8 hafta beslenmiştir. Yapılan çalışma sonunda serum Zn ve Se düzeyleri incelendiğinde, hayvanların rasyonlarına \%5 ve \%10 diatomit katılması ile Zn ve Se düzeylerinde anlamlı farklılıklar olduğu ve \%10 diatomit katkılı yemle beslenen grubun Zn değerlerinin en yüksek olduğu ve \%5'lik diatomit katkısının Se düzeyinde önemli artışa neden olduğu belirlenmiştir. Grupların canlı ağırlık artış ortalamaları sırasıyla 4, 6.2 ve 5,6 kg olarak belirlenmiş, \%5 diatomit katkılı yemle beslenen grubun canlı ağırlık artışı diğer gruplardan daha fazla olduğu belirlenmiştir $(p<0.05)$. Sonuç olarak hayvanların rasyonlarına \%5 diatomit katkısının kan Se düzeyini, \%10 diatomit katkısının kan Zn değerini artırdığı bununla beraber kullanılan diatomitin her iki grupta da canlı ağırlık artışı sağladığı tespit edilmiştir.
\end{abstract}

Anahtar Kelimeler: Canlı Ağırlık, Çinko, Diatomit, Kilis Keçisi, Selenyum.

\section{The Effects of Diatomite on Blood Selenium and Zinc Values and The Live Weight Changes in Kilis Goats}

Abstract: Diatomite is an organic feed additive that is often used as a feed ingredient for livestock and an alternative anthelmintic. In this study, the effects of diatomite, which was added to the diets of Kilis goats, on selenium and zinc figures of the animals' blood and the live weight of goats were investigated. In the study, between 18-42 months old male and female 15 Kilis goats with weights between $23-50 \mathrm{~kg}$ were used. The animals were divided into three groups: the control group, $5 \%$ diatomite added group, and $10 \%$ diatomite added group. Diatomite was not added to the rations of the control group. Up to $5 \%$ of the daily dry feed amount of diatomite was added to the second group of animals' rations. Up to \%10 of the daily dry feed amount of diatomite was added to the third group of animals' rations. All the animals were fed for eight weeks. At the end of the study, when serum $\mathrm{Zn}$ and Se levels were examined, it was determined that there were significant differences in $\mathrm{Zn}$ and Se levels with the addition of $5 \%$ and $10 \%$ diatomite to the rations of the animals. Especially the $\% 10$ diatomite contribution caused a significant increase in $\mathrm{Zn}$, and $5 \%$ diatomite contribution caused a significant increase in Se levels. At the end of the study, the average live weight gain of the groups was $4 \mathrm{~kg}, 6.2 \mathrm{~kg}$, and $5.6 \mathrm{~kg}$, respectively. It was determined that the body weight gain of the group fed with $5 \%$ diatomite supplemented feed was higher than the other groups $(p<0.05)$. Consequently, it was determined that adding $\% 10$ diatomite to the rations of the animals caused an increase in $\mathrm{Zn}$ levels, and adding \%5 diatomite to the rations of the animals caused an increase in Se levels. Moreover, it was stated that adding diatomite provided an increase in the live weight of the animals.

Keywords: Diatomite, Kilis Goat, Live Weight, Selenium, Zinc,

\section{Giriş}

Diatomit, diyatome olarak adlandırılan tek hücreli mikroskobik silisli alglerin suda ölmeleri sonucu hücre çeperlerinin tortul şeklinde birikmesiyle oluşan organik çökeltidir (Taş ve Çetin, 2012). Besi ve kümes hayvanı üretiminde besin katkı maddesi olarak diatomitin tahıl ambarlarında böcek kontrolü ve hayvanlarda parazit kontrolü, mineral kaynağı, absorpsiyon gibi farklı amaçlarla kullanımı rapor edilmiştir. Diatomit genellikle koyun, keçi, sığır, kümes hayvanları ve diğer çiftlik hayvanları için yem bileşeni ve alternatif bir antelmintik olarak kabul edilir (Beltran ve Martin, 2016). Hayvan sağlığı ve beslenmesi için organik bir ürün olarak kabul edilen diatomit koyun, keçi ve diğer çiftlik hayvanları için alternatif doğal antelmintik olmasının yanında etkili bir büyüme destekleyici 
olduğu da iddia edilmektedir (Martel-Kennes ve ark., 2016; Nkwana ve ark., 2019). Diatomitin hayvanlarda besin takviyesi olarak kullanılmasının, verim artışı ve gıda güvenliğine katkıda bulunduğu bildirilmiştir (Köster, 2013). Hayvanlarda yıkıcı ve zehirli tortuları emen etkili bir sindirim yardımcısı olmasının yanı sıra diatomit hayvanların performansını iyileştirmede önemli olan 14 çeşit iz element içerdiği bilinmektedir (Adebiyi ve ark., 2009; Emeruwa ve Anurudu, 2018). Esas olarak amorf silika olan diatomit (>\%86 silikon) sağlık için bir tehlike oluşturmaz. Ayrıca diatomit \%5 sodyum, \%3 magnezyum, \%2 demir, selenyum ve bakır gibi 14 değerli eser element içermektedir (Köster, 2013).

Besicilikte ve kümes hayvanı yetiştiriciliğinde gıda sınıfı diatomit için, böcek ve parazit kontrolü, mineralizasyon, absorpsiyon ve tahıl koruma gibi dört farklı kullanımı bulunmaktadır. Diatomitin, hayvan beslenmesi için organik bir ürün olduğu ve koyun, keçi gibi çiftlik hayvanları için etkili bir büyüme destekleyici ve alternatif doğal antelmintik olduğu bilinmektedir (Nkwana ve ark., 2019).

İz elementler, hayvanların günlük ihtiyaçlarının miligram veya mikrogram seviyesinde olan demir, bakır, manganez, çinko ve selenyum gibi mineraller olup, canlıda birçok yapısal, katalizleyici ve düzenleyici etkileri olduğu, ayrıca bağışıklık sistemi üzerinde de önemli katkıları olduğu bildirilmektedir (Dalı, 2018; Galyean ve ark., 1999). Cu, Zn ve Se gibi bazı iz elementler karbonhidrat, protein ve lipit metabolizmasında anahtar rol oynamalarının yanı sıra hücresel solunum, DNA ve RNA replikasyonu ve serbest radikallerin yok edilmesinde rol oynadıkları bilinmektedir (Vázquez-Armijo ve ark., 2011).

Selenyumun başlıca fonksiyonları; reaktif oksijenlerin hücre membranına ve epitel hücrelere olası zararlarının engellenmesi, antikor sentezinin uyarılması, lökositlerin infeksiyon bölgesine toplanması olarak tanımlanabilir. Bununla birlikte laktasyon döneminde hayvanda görülen mastitisin etkilerinin Se takviyesi ile azaldığı belirtilmiştir (Paksoy ve İriadam 2012; Smith ve ark., 1985).

Selenoproteinler, hücreleri serbest radikallerin verdiği zarardan korur, tiroit hormonlarının metabolizmasına katılır, üreme fonksiyonlarını kontrol eder ve nöroprotektif etki gösterir (TórtoraPérez, 2010; Zarczynska ve ark., 2013). Kuzularda görülen Beyaz Kas Hastalığı yem ve ana sütüyle alınan E vitamini ve selenyumun eksikliği ya da displazenter transport blokajı nedeniyle oluşur. Hastalıklı olan kuzuların kasları güçsüzdür, solunum güçlüğü çekerler ve annelerini ememediklerinden kolostrum alamayıp akut kalp yetmezliğinden kısa sürede ölürler. Hastalık belirtileri görülen bu hayvanlar hastalığın ilk dönemlerinde $E$ vitamini kombinasyonları ile tedavi edilebilirler (Avcı ve ark., 2000; Sugen ve Güneş, 2008; Tórtora-Pérez, 2010).
Dünyanda da yaygın görülen bu hastalık ülkemizde Doğu ve Güneydoğu Anadolu bölgeleri için de önemli bir sorun oluşturmaktadır ( $\mathrm{Avcl}$ ve ark., 2000).

Çinko özellikle; kas doku, kemik, kan, bezler, genital organlar, deri, kıl, yapağı ve tırnaklarda yoğun olarak bulunmaktadır ve hayvanlarda ortalama olarak $30 \mathrm{mg} / \mathrm{kg}$ çinko bulunur. Kan serumunda ortalama \%100-200 $\mu$ g çinko bulunduğu bildirilmektedir. Protein metabolizması, membran bütünlüğünün korunması, leptin ve tiroid hormonlarının aktivitesi ile insülinin sentezi ve immun sistemde görev alan çinko, metabolizmada önemli role sahiptir. Çinkonun antioksidan enzimlerin yapısında bulunması sebebiyle, serbest radikallerin hücreye vereceği zararı önlemek amacıyla yeme eklenmesi önerilmektedir (Durmuş ve Eryavuz, 2012; Dalı,2018). Rasyona yüksek düzeyde çinko eklenmesi ile kuzularda canlı ağırlık artışı, sığırlarda immun sistemin uyarılması, süt üretimi artışı, tırnak hastalıklarında azalma olduğu bildirilmiştir (Patra, 2007).

Yadav ve arkadaşları 2016 yılında 12 barbar keçisiyle 60 gün süreyle deney grubundaki hayvanlara günlük $150 \mathrm{ppm}$ çinko sülfat ve 0,50 ppm sodyum selenat (inorganik çinko ve selenyum) vererek yapmış oldukları çalışmada, ortalama kan glukoz seviyesi, ALT ve AST değerlerinin kontrol grubuna kıyasla önemli ölçüde arttığını tespit etmişlerdir (Yadav ve ark., 2016).

Batı Afrika Cüce Koyunlarının diyetine \%2.0 diatomit eklenmesi, kuru madde alımını arttırdığı ve laktasyon sırasında kilo kaybını azalttığı, ayrıca yeme \% 4.0'lük diatomit katkısının günlük kilo artışını artırdığı tespit edilmiştir (Emeruwa ve Anurudu, 2018). Domuzlarla yapılan bir çalışmada, diatomitin asıl bileşeni olan $\mathrm{SiO}_{2}$ 'in rasyona eklenmesiyle yem alımını ve ortalama günlük kazancı artırdığı belirtilmiştir (Martel-Kennes ve ark., 2016).

Bu çalışmada Kilis Keçilerinin rasyonlarına yem katkısı olarak belli oranlarda katılan diatomitin, kan Se (selenyum) ve Zn (çinko) düzeyleri ile canlı ağırlık artışına olan etkisinin incelenmesi amaçlanmıştır.

\section{Materyal Metod}

Araştırmada Harran Üniversitesi Araştırma Uygulama çiftliğinde bulunan yaşları 18-42 ay arasında değişen ve canlı ağırlıkları 23-50 kg arasında 15 Kilis keçisi kullanıldı. Ticari firmadan temin edilen işlenmemiş diatomit hayvan yemlerine katılarak deney süresi boyunca tasarlanan programa uygun olarak tüm hayvanların düzenli olarak beslenmesi sağlandı. Deney grupları, her grup farklı yaş, ağırlık ve cinsiyette 5 hayvandan oluşacak şekilde 3 grup olarak belirlendi. I. Gruba (kontrol grubuna) normal yem ve su verildi; II. Gruba günlük 
$1,5 \mathrm{~kg}$ kuru yem miktarının \%5'i olan 75 gr diatomit katkısı yapıldı; III. Gruba günlük 1,5 kg kuru yem miktarının \%10'u olan $150 \mathrm{gr}$ diatomit katkısı yapıldı. Gruplar oluşturulduktan sonra hayvanların canlı ağırlık tartımı yapılıp farklı gruplar ayrı olacak şekilde farklı kısımlara yerleştirildiler. Sekiz hafta sonunda tekrar tartımları yapıldı.

Tüm gruplardaki hayvanlardan iz element analizleri için juguler venadan antikoagülansız tüplere alınan örnekler 4000 devirde 10 dakika santrifüj edilerek elde edilen serum örnekleri Eppendorf tüplerine aktarılarak -80 을 de muhafaza edildi. Hayvanların tartımı yapılıp kayıt altına alındı.

Sekiz hafta boyunca her 15 günde 1 defa kan örnekleri alınıp iz element analizleri için 4000 devirde 10 dakika santrifüj edilerek elde edilen serum örnekleri Eppendorf tüplerine aktarılarak 80 ㄷ' de saklandı. Sekizinci haftanın sonunda tüm hayvanların tartımı yapılıp kayıt altına alındı.

İz element analizi için numuneler 0,5 gr ile 1,5 gr tartılmış, üzerine 10 mililitre nitrik asit eklenip (Cem mars 5) mikrodalga cihazında $160^{\circ} \mathrm{C} 1600$ Watt \%100 güçte 40'süre ile çözme işlemine tabi tutuldu. Tüm numuneler $50 \mathrm{ml}$ hacme tamamlandıktan sonra standart Perkin Elmer solüsyonu kullanılarak ICP-MS (Perkin Elmer ElanDRC-e) cihazında iz element analizleri yapılmış ve her 10 analizden sonra standart okuma yapıldı. Se için kalibrasyon 1000 ppb, Zn için de 2000 ppb olarak belirlenmiş ve korelasyon katsayısı (R) minimum 0.999 olarak ayarlanmıştır.
Tüm veri analizlerinin değerlendirilmesinde Windows yazılımı için Minitab 17 paket programı kullanıldı. Veriler varyans eşitlik varsayımı için Levene testi ve normallik varsayımı için Shapiro Wilk testi ile istatistiksel olarak analiz edildi ( $p>0.05)$. Zn ve Se elementlerinin zaman ve uygulamalarının ANOVA analizleri, anlamlı çıkan sonuçların gruplar arası farkları belirlemek için Tukey çoklu karşılaştırma testi ile yapıldı. Tüm testlerde önem derecesi $p<0.05$ 'te hesaplandı.

\section{Bulgular}

Zn ve Se bulguları değerlendirildiğinde başlangıçtan 8. haftanın sonuna kadar kontrol grubu, \%5 ve \%10 diatomit katkılı yemle beslenen gruplar için $\mathrm{Zn}$ ve Se değerlerinde anlamlı farklılıklar olduğu belirlenmiştir (Tablo 1). Serum Zn ve Se değerleri kontrol grubu hayvanlarına göre artış göstermiştir $(p<0.05)$. Kontrol grubu değerlerine göre \%5 ve \%10 diatomit katkılı yemle beslenen hayvanlarda $\mathrm{Zn}$ değerlerinin daha yüksek olduğu belirlenmiş ve \%10 diatomit katkılı yemle beslenen grubun Zn değerleri en yüksek olduğu tespit edilmiştir. Se değerleri incelendiğinde ise \%5 diatomit katkılı yemle beslenen hayvanların değerlerinin diğer gruplara göre daha yüksek olduğu tespit edilmiş, \%10 diatomit katkılı yemle beslenen hayvanların değerlerinin de kontrol grubuna göre yüksek olduğu belirlenmiştir.

Tablo 1: Kontrol grubu, $\% 5$ ve $\% 10$ katkılı yemle beslenen grupların Zn ve Se ortalamaları (ppb, $n=15)$.

\begin{tabular}{|c|c|c|c|c|c|c|c|c|}
\hline & & Başlangıç & 2. Hafta & 4. Hafta & 6. Hafta & 8. Hafta & Ortalama & $\mathbf{p}$ \\
\hline \multirow{4}{*}{$\mathrm{Zn}$} & Kontrol & 1141,77 & 288,93 & 551,12 & 315,25 & 1289,62 & $717,37 \pm 858,73$ & \multirow{4}{*}{$0.0047^{* *}$} \\
\hline & \%5 Diatomit & 736,07 & 2117,48 & 1154,88 & 305,37 & 2920,67 & $1446,89 \pm 1663,44$ & \\
\hline & \%10 Diatomit & 2485,54 & 2613,37 & 298 & 330,76 & 2178,41 & $1581,22 \pm 1871,48$ & \\
\hline & Ortalama & 1454,46 & 1673,26 & 668,00 & 317,13 & 2129,57 & & \\
\hline \multirow{4}{*}{$\mathrm{Se}$} & Kontrol & 139,2 & 139,98 & 185,62 & 123,21 & 112,11 & $140.02 \pm 91.01$ & \multirow{4}{*}{$0.0363^{*}$} \\
\hline & \%5 Diatomit & 240,62 & 151,01 & 399,91 & 129,07 & 198,82 & $223.89 \pm 156.14$ & \\
\hline & \%10 Diatomit & 55,59 & 96,18 & 297,56 & 110,41 & 186,52 & $149.25 \pm 118.49$ & \\
\hline & Ortalama & 145,14 & 129,06 & 294,36 & 120,90 & 165,82 & & \\
\hline
\end{tabular}

Grupların Zn değerlerinin haftalar içindeki etkileşimleri Şekil 1 ve Se etkileşimleri de Şekil 2 de görülmektedir. Başlangıç, 2., 4., 6. ve 8. hafta iz element değerlerinin zamana göre değişimi incelendiğinde; kontrol grubu, $\% 5$ ve $\% 10$ diatomit katkılı yemle beslenen gruplar için; Serum $\mathrm{Zn}$ ve Se değerlerinde başlangıçtan 8 . haftanın sonuna kadar istatistiksel olarak anlamlı farklar olduğu tespit edilmiştir. Kontrol grubu Zn değeri başlangıç değerine göre 2. hafta düşüş göstermiş, 4. hafta az bir oranda artmışsa da 6. hafta tekrar düşüş görülmüştür. Sekizinci hafta ortalaması diğer tüm değerlere göre yüksek çıkmıştır. \%5 diatomit uygulanan grubun $\mathrm{Zn}$ değerleri incelendiğinde ise, 


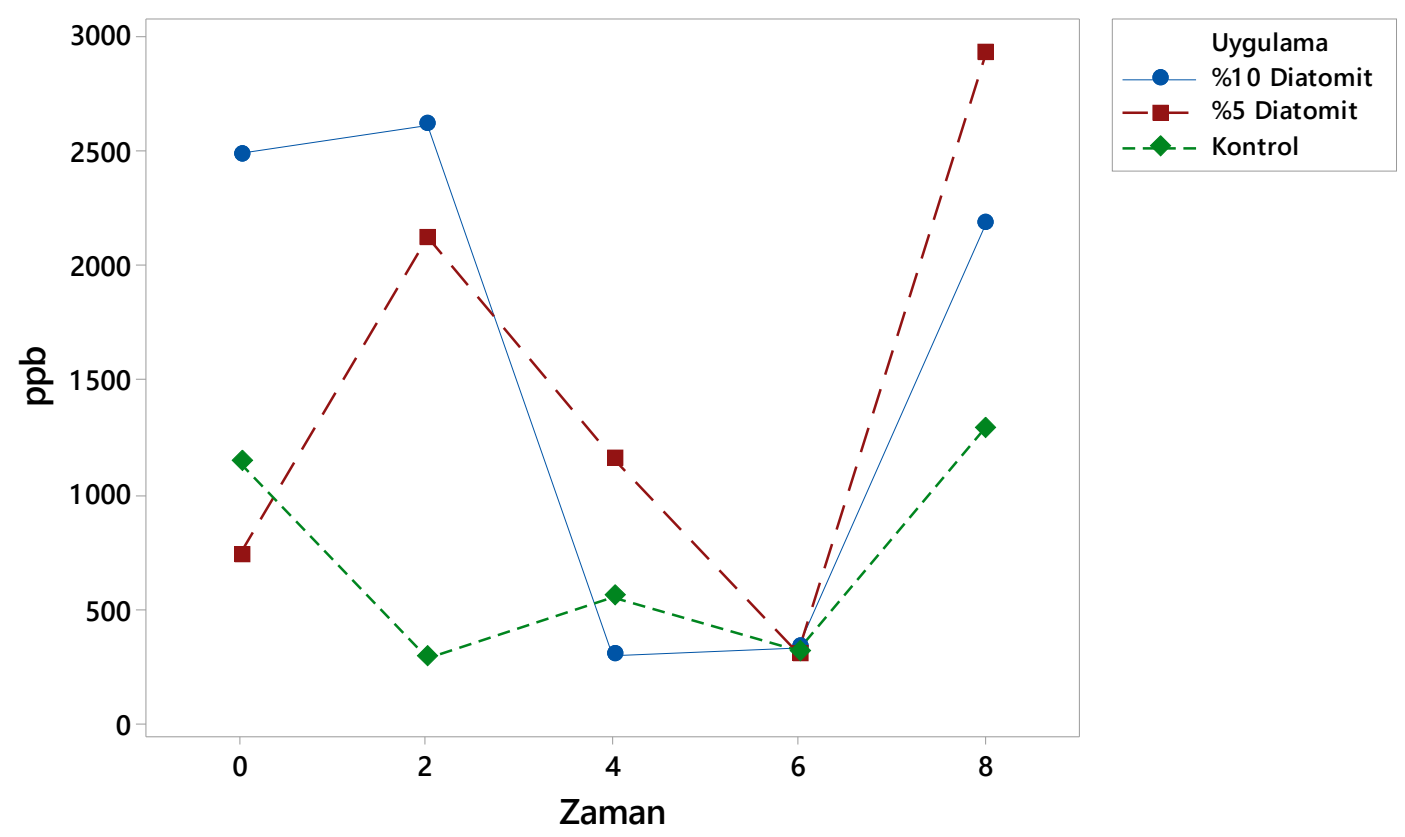

Şekil 1: \%5 ve \%10 diatomit katkısı yapılan hayvan gruplarının Zn etkileşimleri ( $n=5, p p b)$.

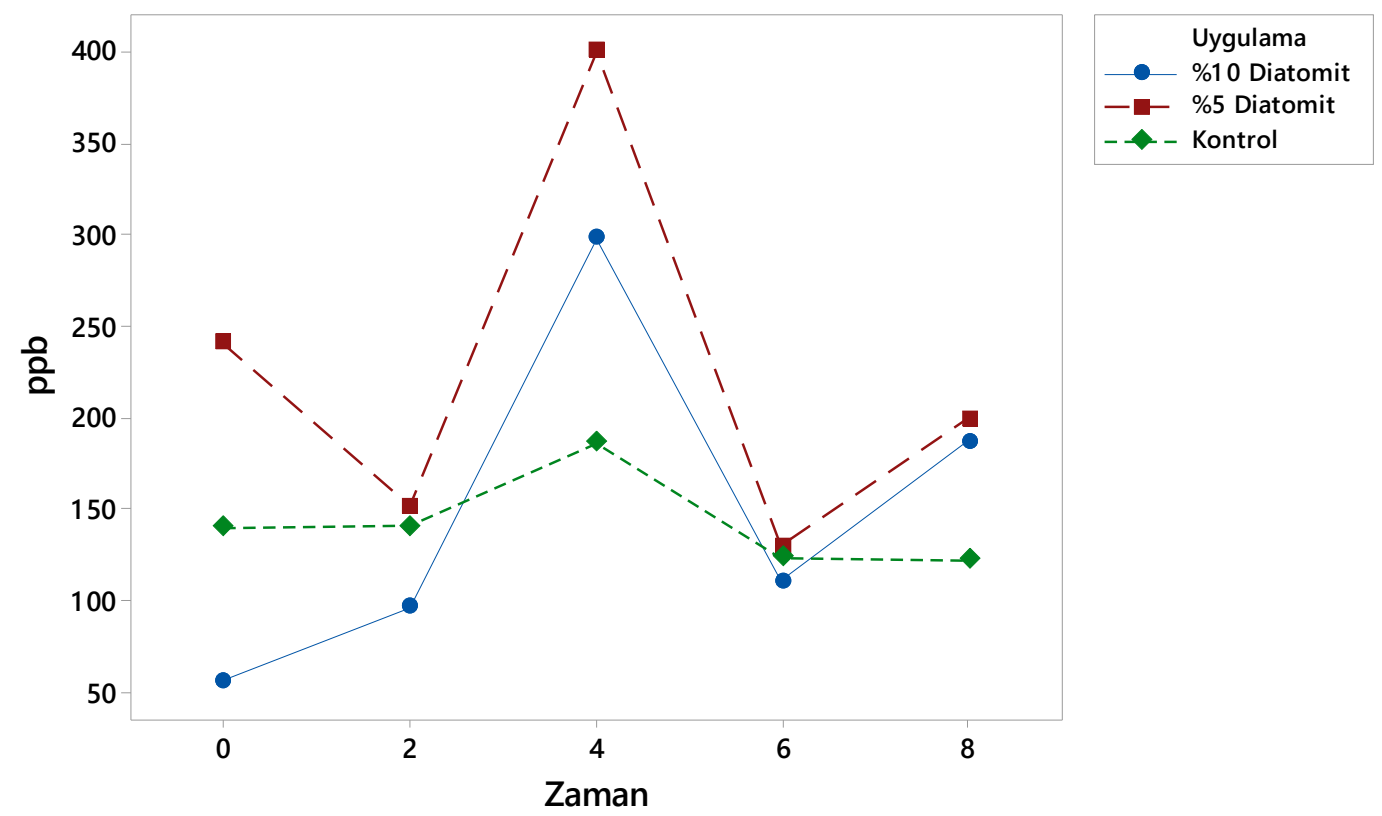

Şekil 2: \%5 ve \%10 diatomit katkısı yapılan hayvan gruplarının Se etkileşimleri ( $n=5, p p b)$.

2. hafta ölçülen değer başlangıç değerine göre yüksek olduğu tespit edilmiş, Zn değeri 6. haftaya kadar düşüş göstermiştir. 8. hafta en yüksek değer tespit edilmiştir. \%10 diatomit uygulanan grubun değerleri incelendiğinde, 2 . hafta ortalaması başlangıç değerine göre hafif artış gösterse de 6 . Haftaya kadar düşüş görülmüş olup 8. hafta önemli ölçüde yükselmiştir. Her grupta da 8. hafta Zn değerleri önemli oranda yükseliş göstermiştir (Şekil 1).
Serum selenyum değerlerinin 8 haftalık etkileşim ortalamalarına bakıldığında, kontrol grubunda 4. haftaya kadar düşük bir yükseliş tespit edilse de 8 . haftanın sonunda Se değeri düşmüştür. Başlangıç değerine göre $\% 5$ diatomit uygulanan grupta 2. hafta ortalama değer düşüş göstermiş 4 . hafta yükselen ortalama değer 6 . hafta önemli oranda düşmüş ve 8 . hafta sonunda tekrar yükseliş göstermiştir. \%10 diatomit uygulanan grupta ise 2 . hafta ölçülen değer başlangıç değerine göre düşük 
olarak belirlenmiş fakat 4 . hafta en yüksek değere ulaşmış olup 6. hafta değeri en düşük seviyede tespit edilmiş 8. hafta tekrar yüksek olarak belirlenmiştir. Her grupta da dördüncü hafta ölçülen değer en yüksek değer olarak belirlenmiştir (Şekil 2).

Canlı ağırlık bulguları değerlendirildiğinde kontrol grubu kontrol grubu canlı ağırlık ortalaması başlangıçta düşük $(36 \pm 9,92)$ iken 8 . hafta yapılan tartımda en yüksek $(38 \pm 9,08)$ olduğu görülmüştür. Kontrol grubunda canlı ağırlık artışının zamana bağlı olarak anlamlı bir şekilde arttığı gözlemlenmiştir $(p<0.05)$. Buna göre can ağırlık ortalaması başlangıç ölçümünde en düşük iken 8. hafta ölçümünde en yüksek değere sahip olduğu görülmüştür. Sekiz hafta $\% 5$ ve \%10 diatomit katkılı yem ile beslenen gruplarda da canlı ağırlıkların zamana bağlı olarak istatistiksel farklılık gösterdiği belirlenmiştir $(p<0.05)$. Elde edilen sonuçlara göre başlangıçta \%5 diatomit verilen grubun ağırlık ortalaması $(34.20 \pm 8.23)$ ve $\% 10$ diatomit verilen grubun ortalaması $(48.80 \pm 22.6)$ iken 8 . hafta sonunda en yüksek değerlerde $(40.40 \pm 9.07)$ ve $(54.40 \pm 20.18)$ olduğu tespit edilmiştir (Tablo 2).

Tablo 2: Canlı ağırlıkların zamana göre değişimi.

\begin{tabular}{llcccc}
\hline Zaman & Birim & n & Kontrol Grubu & Katkılı Yem & Katkılı Yem \\
\hline Başlangıç & $\mathrm{kg}$ & 5 & $36.00 \pm 9,92^{\mathrm{B}}$ & $34.20 \pm 8.23^{\mathrm{B}}$ & $48.80 \pm 22.60^{\mathrm{C}}$ \\
4. Hafta & $\mathrm{kg}$ & 5 & $37.00 \pm 9,35^{\mathrm{AB}}$ & $36.80 \pm 8.41^{\mathrm{B}}$ & $51.20 \pm 21.10^{\mathrm{B}}$ \\
8. Hafta & $\mathrm{kg}$ & 5 & $38.00 \pm 9,08^{\mathrm{A}}$ & $40.40 \pm 9.07^{\mathrm{A}}$ & $54.40 \pm 20.18^{\mathrm{A}}$ \\
\hline
\end{tabular}

\section{Tartışma ve Sonuç}

Canlıların yaşaması için çok önemli olan iz elementlerin eksikliğinde çeşitli rahatsızlıklar ortaya çıkmaktadır (Batmaz 2014). Yem katkı maddesi olarak yaygın şekilde kullanılan diatomitin organik hayvancılıkta iz element kaynağı olabileceği düşünülmektedir (Bernard ve ark., 2009). Galyean ve arkadaşları (1999) normal bağışıklık fonksiyonu ve hastalık direnci için önemli olduğu belirlenen $\mathrm{Zn}$, $\mathrm{Cu}$, Se ve $\mathrm{Cr}$ gibi iz elementlerin yeni doğan buzağılara takviye olarak verilmesinin bağışıklık fonksiyonunu etkilediğini belirtmişlerdir. Smith ve arkadaşları, süt sığırlarında ilk laktasyonda Se takviyesi ile mastitisin klinik semptomlarının görülme sıklığının ve şiddetinin azalttığını bildirilmiştir. Emeruwa ve ark. (2018) ve Adebiyi ve ark. (2009) diatomitin hayvanlar için önemli olan Se ve $\mathrm{Zn}$ gibi iz elementlerin kaynağı olduğunu vurgulamışlardır. Bu çalışmada ise Serum $\mathrm{Zn}$ ve Se düzeyleri açısından bakıldığında günlük rasyona $\% 5$ ve \%10 diatomit katkısı $\mathrm{Zn}$ ve Se düzeylerinde anlamlı farklılıklara neden olurken özellikle, \%10 diatomit katkısının Zn düzeylerinde ve $\% 5$ diatomit katkısının da Se düzeyinde önemli artışa neden olduğu görülmüştür (Tablo 1 1). 15 günlük etkileşimler incelendiğinde da $\mathrm{Zn}$ değerlerinin \%5 diatomit katkılı yemle beslenen grubun $\mathrm{Zn}$ değerlerinin 8. haftanın sonunda en yüksek artış gösterdiği, \% 10 diatomit katkılı yemle beslenen grubun da 8. hafta değerinin önemli oranda arttığı belirlenmiştir (Şekil 1). Se değerlerinin de \%5 ve \%10 diatomit katkılı yemle beslenen gruplarda 4 . hafta en yüksek değerde olduğu tespit edilmiştir (Şekil 2). Elde edilen bu veriler Emeruwa ve ark. ile Adebiyi ve ark. belirttikleri gibi diatomitin hayvanlar için Se ve Zn kaynağı olabileceğini desteklemektedir; bununla beraber yem katkı maddesi olarak diatomitin etkisini incelediğimiz bu iz elementler için daha önce yapılmış çalışmalara rastlanılmamıştır.

Bennett ve ark. (2011) ve Ahmed, Laing ve ark. (2013) tarafından da diatomitin deney hayvanlarının vücut ağırlığını, yemden yararlanma ve büyüme oranını önemli ölçüde artırdığını ve parazit yükünü azalttığı ifade edilmiştir. Bıldırcın yavrularının kullanıldığı bir çalışmada, aflatoksin içeren bir diyete diatomit eklenmesinin, aflatoksinin canlı ağırlığı artışı üzerindeki olumsuz etkisini önemli ölçüde azalttığını gözlemlemişlerdir. Etlik piliçlerin, sırasıyla 400 ve 800 mg/kg'da diatomit, önemli ölçüde daha fazla vücut ağırlığına ve daha az yem dönüştürme oranına ve serum toplam protein ve albümin değerlerinde bir artışa neden olduğunu bildirmiştir (Parlat ve ark., 1999). Lakkawar ve arkadaşları, diatomitin etlik piliçlerin yemlerine 400 ve 800 $\mathrm{mg} / \mathrm{kg}$ eklendiğinde büyüme parametreleri ve serum biyokimyasal değerleri üzerindeki zararlı etkilerini önemli ölçüde azalttığı kaydedilmiştir (Lakkawar ve ark., 2016). Ewuola ve arkadaşları ortalama ağırlık artışı, yemden yararlanma ve yem katkı maddesi olarak \% 6 diatomit katkısı ile 
beslenen yavru horozların kemik gelişiminde önemli bir iyileşme olduğunu bildirmişlerdir (Ewuola ve ark., 2014). Martel ve arkadaşlarının yaptığı bir çalışmada, 252 domuz yavrusunun yemine diatomitin asıl bileşeni olan $\mathrm{SiO}_{2}$ eklenerek yem alımını $\% 4,13$ oranında ve ortalama günlük kazancını \%3,26 oranında artırdığı kaydedilmiştir (Martel-Kennes ve ark., 2016). Isabirye ve arkadaşlarının 2021 yılında 200 tavuk üzerinde 24 hafta süresince yapmış oldukları çalışma sonunda \%4 diatomit uygulanan gruplarda kontrol grubuna göre canlı ağırlık artışında anlamlı fark tespit edilmemiştir (Isabirye ve ark., 2021).

$\mathrm{Bu}$ çalışmada günlük rasyona $\% 5$ ve $\% 10$ diatomit katkısı yapıldığında elde edilen sonuçlar Isabirye ve arkadaşlarının aksine Bennet, McLean, Lakkawar, Ewuola, Martel ve bunların arkadaşlarının yaptıkları çalışmalarda elde ettikleri sonuçları destekler nitelikte olduğu görülmüştür. Günlük rasyona \%10 diatomit katkısı ile hayvanların canlı ağırık artışlarının daha fazla olduğu tespit edilmiştir. Kontrol grubuna göre canlı ağırlık artışının \%5 ve \%10 diatomit katkısı verilen gruplarda daha fazla olduğu gözlemlenmiştir.

Sonuç olarak Zn ve Se'un kanda düşük seviyede bulunması hayvanlarda verim ve üreme yönünden ölümlere ve önemli ölçüde ekonomik kayıplara neden olabileceği düşünülürse, bu çalışmada rasyona diatomit ilavesinin kan $\mathrm{Zn}$ ve Se seviyelerini arttırmasının hayvanların genel sağlığı üzerine olumlu etkiler meydana getireceği öngörülmektedir. Böylelikle hayvanların iz element eksikliğinde özellikle de beyaz kas hastalığını önleyici amaçla diatomit kullanımı önerilebilir. Ayrıca diatomit kullanımının hayvanların canlı ağırık artışında etkili olabileceği, bununla birlikte diatomitin hayvanlara bilinçli şekilde verilmesi gerektiği, böylece verimin artırılıp, kayıpların önlenmesi mümkün olabilir. Bununla birlikte konu ile ilgili daha kapsamlı çalışmaların yapılmasının gerekliliğinin yanı sıra yapılan bu çalışmanın gelecekte yapılacak araştırmalar için önemli bir zemin oluşturabileceği düşünüldü.

\section{Kaynaklar}

Adebiyi O, Sokunbi O, Ewuola E, 2009: Performance evaluation and bone characteristics of growing cockerel fed diets containing different levels of diatomaceous earth. Middle East J. Sci, Res 4, 36-39.

Ahmed M, Laing M, Nsahlai I, 2013: Studies on the ability of two isolates of Bacillus thuringiensis, an isolate of Clonostachys rosea $\mathrm{f}$. rosea and a diatomaceous earth product to control gastrointestinal nematodes of sheep. Biocontrol Science and Technology, 23(9), 1067-1082.
Avcı M, Karakılçık Z, Kanat R, 2000: Vitamin A, E ve selenyumun koyunlarda döl verimi ve bazı biyokimyasal parametre düzeyleri ile kuzularında yaşama gücü ve canlı ağırlık üzerine etkisi. Turkish Journal of Veterinary and Animal Sciences, 24(1), 4550.

Batmaz M, 2014: Siverek Bölgesinde Koyunlarda Selenyum, Bakır Ve Çinko Seviyelerinin Araştırılması. Yüksek Lisans Tezi, Harran Üniversitesi Sağlık Bilimleri Enstitüsü, Şanlıurfa.

Beltran M, Martin R, 2016: Diatomaceous earth inhibited the in vitro migration of oesophagustomum dendatum larvae. Philippine Journal of Veterinary and Animal Sciences, 41(2).

Bennett D, Yee A, Rhee Y, Cheng Y, 2011: Effect of diatomaceous earth on parasite load, egg production, and egg quality of free-range organic laying hens. Poultry Science, 90(7), 1416-1426.

Bernard G, Worku M, Ahmedna M, 2009: The effects of diatomaceous earth on parasite-infected goats. Bull. Georgian Natl. Acad. Sci 3, 129-135.

Dalı i, 2018: Kahramanmaraş merkez ilçelerindeki koyunlarda demir, bakır ve çinko seviyelerinin araştırılması. Yüksek Lisans Tezi, HRÜ Sağlık Bilimleri Enstitüsü, Şanlıurfa.

Durmuş I, Eryavuz A, 2012: Ruminant hayvanlarda yüksek çinko tüketiminin etkileri. Kocatepe Veteriner Dergisi 5(2), 35-41.

Emeruwa C, Anurudu N, 2018: Performance of pregnant West African Dwarf ewes fed diets supplemented with varying levels of fossil shell flour. 10th International Livestock Environment Symposium (ILES X), American Society of Agricultural and Biological Engineers, St. Joseph, Michigan, pp. 1-6.

Ewuola E, Adebiyi O, Sokunbi O, 2014: Haematological and some serum biochemical response of growing cockerels to dietary diatomaceous earth. J. Anim. Sci. Adv, 4(1), 699-704.

Galyean M, Perino L, Duff G,1999: Interaction of cattle health/immunity and nutrition. Journal of Animal Science 77(5), 1120-1134.

Isabirye RA, Biryomumaisho S, Okwee-Acai J, Okello S, Nasinyama GW, 2021: Effect of diatomaceous earth on growth rate, egg production, feed conversion efficiency and parasitic load in hens raised on deep litter. European journal of agriculture and food Sciences, 3(1):97-103.

Köster H, 2013: https://agrisilica.co.za/en/8-diatomite-inanimal-feeds, Erişim tarihi 15.04.2013.

Lakkawar A, Sathyanarayana M, Narayanaswamy H, Yathiraj S, Shridhar N, Krishnaveni N, 2016: Efficacy of diatomacious earth in amelioration of aflatoxin induced toxicity in broiler chicken. Indian Journal of Animal Research 50(4),529-536.

Martel-Kennes Y, Lévesque J, Decaux C, 2016: Effect of crystalline silicon dioxide in piglet feed on growth performance with different levels of growth promoters. Journal of Animal Science 94, 488-488.

Nkwana A, Hoon J, Fourie P, 2019: The effect of different inclusion levels of diatomaceous earth in feedlot diets on the performance of lambs. Grootfontein Agric, 19(1), 66-72. 
Paksoy N, İriadam M, 2012: Kilis keçilerinde serum selenyum düzeylerinin araştırılması. Harran Üniversitesi Veteriner Fakültesi Dergisi 1(1), 6-8.

Parlat S, Yildiz A, Oguz H, 1999: Effect of clinoptilolite on performance of Japanese quail (Coturnix coturnix japonica) during experimental aflatoxicosis. British poultry science 40(4), 495-500.

Patra A, 2007: Nutritional management in organic livestock farming for improved ruminant health and production. An overview. Livest. Res. Rural Dev 19(3), 41.

Smith K, Conrad H, Amiet B, Schoenberger $P$ and Todhunter D, 1985: Effect of vitamin E and selenium dietary supplementation on mastitis in first lactation dairy cows. J. Dairy Sci 68(Suppl 1), 190.

Sugen B, Güneş V, 2008: Beyaz kas hastalıklı kuzularda kalp kası hasarının teşhisinde kardiyak troponin kit analizleri ve serum enzim aktivitelerinin önemi. Sağlık Bilimleri Dergisi 17(3), 144-149.

Taş B, M. Çetin, 2012: Biyolojik orijinli tek doğal mineral: diyatomit. Tübav Bilim Dergisi 5(2), 28-46.
Tórtora-Pérez, J, 2010: The importance of selenium and the effects of its deficiency in animal health. Small Ruminant Research 89(2-3), 185-192.

Vázquez-Armijo J, Rojo J,López D, Tinoco J, González A, Pescador N, Domínguez-Vara I, 2011: Trace elements in sheep and goats reproduction: A review. Tropical and Subtropical Agroecosystems 14(1), 1-13.

Yadav A, Kumar J, Anand M, Swain D, Yadav D, 2016: Effect of zinc and selenium supplementation on blood biochemical profile in pure bred Barbari goat. Veterinary Practitioner 17(1): 110-111.

Zarczynska K, Sobiech P, Radwinska J, Rekawek W, 2013: Effects of selenium on animal health. Journal of Elementology, 18(2).

*Yazışma Adresi: Mehmet Şevki ÇADIRCI

TOBB Fen Lisesi Müdürlüğü, Haliliye, Şanlıurfa, Türkiye.

e-mail:msevkic@harran.edu.tr 